\title{
Development of fermented and flavoured kefir milk
}

\author{
Aline Melo ${ }^{1 *}$, Maria Aparecida Silva ${ }^{2}$ \\ From 5th Congress of the Brazilian Biotechnology Society (SBBIOTEC) \\ Florianópolis, Brazil. 10-14 November 2013
}

Kefir is a dairy beverage, obtained from lactic acid and alcoholic fermentation of its grains, which resembles yogurt in its flavour, aroma and consistency. It is composed of approximately 15-16 lactobacilli, approximately 7-9 streptococci/lactococci, 8 yeasts and 2 acetic bacteria (acetobacter). The fermenting action of Kefir bacteria and yeasts increases the biological value of milk, increasing synthesis of the B group vitamins, which help in the digestive process. The abundance in Calcium, Phosphor, and Magnesium is another of Kefir's characteristics, as for all other dairy products. It is an easily digested product that eliminates harmful bacteria and yeasts from the intestine, increases beneficial and protective bacterial population, and as a probiotic food has many therapeutic applications. This study had as its objective the production of fermented milk based on Kefir, when different flavours were tested, to have it sensorial tested to find the one with the highest acceptance. Firstly, an analysis of the total coliform content was performed, followed by a microbiological quantification analysis of the colony-forming-unit per gram $(\mathrm{CFU} / \mathrm{g})$, to ensure the quality of the product to be offered to tasters. Secondly, the Kefir milk was flavoured with 4 different flavours (passion fruit, strawberry, grape and mango), where juice from concentrate pulp and fruit bits were used, served to 60 tasters (students, professors and staff from UNISO), according to the model for rankpreference test (164/IV 'Testes Efetivos - Testes de preferência' Effective Test - PreferenceTests) according to the Instituto Adolfo Lutz.

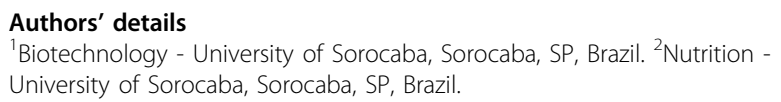

Published: 1 October 2014

'Biotechnology - University of Sorocaba, Sorocaba, SP, Brazil

Full list of author information is available at the end of the article

\section{References}

1. ANVISA: Agência Nacional de Vigilância Sanitária: Alimentos com Alegações de Propriedades Funcionais e ou de Saúde, Novos Alimentos/ Ingredientes, Substâncias Bioativas e Probióticos. [http://www.anvisa.gov. br/alimentos/comissoes/tecno_lista_alega.htm].

2. Credidio E: Alimentos funcionais na nutrologia médica. 2008, 4a Itu: Ottoni.

3. Zenebon $\mathrm{O}$, et al: Análise sensorial. In Métodos Físico-Químicos para Análise de Alimentos Zenebon O \& Pascuet NS. São Paulo: Instituto Adolfo Lutz , 4 2005, 279-320.

doi:10.1186/1753-6561-8-S4-P15

Cite this article as: Melo and Silva: Development of fermented and flavoured kefir milk. BMC Proceedings 2014 8(Suppl 4):P15.
Submit your next manuscript to BioMed Central and take full advantage of:

- Convenient online submission

- Thorough peer review

- No space constraints or color figure charges

- Immediate publication on acceptance

- Inclusion in PubMed, CAS, Scopus and Google Scholar

- Research which is freely available for redistribution
() Biomed Central
C Biomed Central

(c) 2014 Melo and Silva; licensee BioMed Central Ltd. This is an Open Access article distributed under the terms of the Creative Commons Attribution License (http://creativecommons.org/licenses/by/4.0), which permits unrestricted use, distribution, and reproduction in any medium, provided the original work is properly cited. The Creative Commons Public Domain Dedication waiver (http://creativecommons.org/publicdomain/zero/1.0/) applies to the data made available in this article, unless otherwise stated. 